\title{
Jesus, psychological type and conflict: A study in biblical hermeneutics applying the reader perspective and SIFT approach to Mark 11:11-21
}

\begin{tabular}{|c|c|}
\hline \multicolumn{2}{|c|}{$\begin{array}{l}\text { Authors: } \\
\text { Leslie J. Francis } \\
\text { Tania ap Siôn }{ }^{1,2}\end{array}$} \\
\hline \multicolumn{2}{|c|}{$\begin{array}{l}\text { Affiliations: } \\
{ }^{1} \text { Warwick Religions and } \\
\text { Education Research Unit, } \\
\text { University of Warwick, } \\
\text { United Kingdom }\end{array}$} \\
\hline $\begin{array}{l}{ }^{2} \text { Department } \\
\text { Testament Stu } \\
\text { Theology, Univ } \\
\text { Pretoria, Soutl }\end{array}$ & $\begin{array}{l}\text { f New } \\
\text { dies, Faculty of } \\
\text { /ersity of } \\
\text { Africa }\end{array}$ \\
\hline \multicolumn{2}{|c|}{$\begin{array}{l}\text { Project leader: A.G. van Aarde } \\
\text { Project number: } 2334682\end{array}$} \\
\hline \multicolumn{2}{|c|}{$\begin{array}{l}\text { Description: } \\
\text { Prof. Dr Leslie J. Francis and Dr } \\
\text { Tania ap Siôn are participating } \\
\text { as research fellows in the } \\
\text { project 'Biblical Theology and } \\
\text { Hermeneutics', directed by } \\
\text { Prof. Dr Andries G. van Aarde, } \\
\text { professor emeritus and senior } \\
\text { research fellow in the Faculty } \\
\text { of Theology of the University } \\
\text { of Pretoria, South Africa. }\end{array}$} \\
\hline \multicolumn{2}{|c|}{$\begin{array}{l}\text { Corresponding author: } \\
\text { Leslie Francis, } \\
\text { leslie.francis@warwick.ac.uk }\end{array}$} \\
\hline \multicolumn{2}{|c|}{$\begin{array}{l}\text { Dates: } \\
\text { Received: } 06 \text { June } 2016 \\
\text { Accepted: } 29 \text { Aug. } 2016 \\
\text { Published: } 17 \text { Nov. } 2016\end{array}$} \\
\hline \multicolumn{2}{|c|}{$\begin{array}{l}\text { How to cite this article: } \\
\text { Francis, L.J., \& Ap Siôn, T., } \\
2016 \text {, 'Jesus, psychological } \\
\text { type and conflict: A study in } \\
\text { biblical hermeneutics applying } \\
\text { the reader perspective and } \\
\text { SIFT approach to Mark } \\
\text { 11:11-21', HTS Teologiese } \\
\text { Studies/Theological Studies } \\
\text { 72(4), a3573. http://dx.doi. } \\
\text { org/10.4102/hts.v72i4.3573 }\end{array}$} \\
\hline \multicolumn{2}{|l|}{ Read online: } \\
\hline 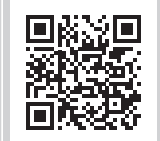 & $\begin{array}{l}\text { Scan this QR } \\
\text { code with your } \\
\text { smart phone or } \\
\text { mobile device } \\
\text { to read online. }\end{array}$ \\
\hline
\end{tabular}

The Marcan account of Jesus riding into Jerusalem on a donkey, cursing the fig tree and overturning the tables of the money changers in the temple provides a classic scriptural reference point for a Christian discussion of conflict. Drawing on psychological type theory and on the reader perspective proposed by the SIFT (sensing, intuition, feeling and thinking) approach to biblical hermeneutics and liturgical preaching, this study tests the theory that different psychological types will interpret this classic passage differently. Data collected in two residential programmes concerned with Christianity and conflict from type-aware participants confirmed characteristic differences between the approaches of sensing types and intuitive types and between the approaches of thinking types and feeling types.

\section{Introduction}

The Christian community is not immune from conflict - within churches, between churches and between churches and the secular world. Christian reflection on conflict can be resourced from many sources, including doctrine, tradition and scripture. An example from scripture resourcing Christian reflection on conflict concerns the narrative of Jesus' entry into Jerusalem as recorded by Mark, combining the cursing of the fig tree and the cleansing of the temple.

The Marcan narrative (Mk 11:11-21) is distinctive in several ways. In Mark's account, Jesus entered Jerusalem, went into the temple, looked around at everything and then went out to Bethany for the night with the twelve. The following day Jesus returned, saw the fig tree in the distance, went to the fig tree looking for figs, found none and cursed the fig tree. Then Jesus entered the temple for the second time, drove out the money changers, overturned the tables, prevented people from carrying anything through the courtyard of the temple and proclaimed judgement on the people there. The next day the fig tree had withered away to its roots.

The Matthean narrative (Mt 21:12-22) accelerated the Marcan account and disconnected the Marcan enclosure of the cleansing of the temple within the incident of the fig tree. As Matthew related the tradition, the cleansing of the temple took place immediately on Jesus' entry to Jerusalem. There was no time to go back to Bethany overnight and to delay the actions of cleansing until the following day. As Matthew relates the tradition, Jesus encountered the fig tree on the day following the cleansing of the temple, he cursed the fig tree and it withered at once before their very eyes. The disciples marvelled and asked, 'How did the fig tree wither at once?'

The Lucan narrative (Lk 19:45-47) seriously condensed the Marcan account but prefaced it with prophetic interpretation. When Jesus drew near and saw the city, he wept over it and prophesised the siege and destruction of Jerusalem. After the prophecy, the drama of the cleansing of the temple was glossed over and the controversy against Jesus was softened. The incident of the fig tree was removed from the Lucan narrative.

The Johannine narrative (Jn 2:13-22) reinterpreted the whole incident of the cleansing of the temple and transitioned the event from the introduction to the Passion narrative to the opening of the Gospel in chapter 2, but kept it within the timeframe of the Passover. As John related the tradition, the drama and the conflict were heightened. According to John, Jesus made a whip of cords, drove out the dealers and the money changers, drove out sheep and oxen, scattered the money and overturned the tables. Here was a dramatic ending to the functions of the old temple, with a reference to Jesus' own body as fulfilling the functions of the temple. There is no rationale for the incident of the fig tree to be related in the Johannine account. 


\section{Reader perspective}

The foregoing analysis of the four accounts of the cleansing of the temple as portrayed by the Gospels of Mark, Matthew, Luke and John stands broadly within the redaction-critical approach to the gospel narratives. Building on insights afforded by source criticism (see Sparks 1964) and form criticism (see Dibelius 1971), redaction criticism directed attention to the creative contribution of the individual authors themselves (see Rohde 1968). In this sense redaction criticism tries to access the individual redactional contributions of the gospel writers. While the redaction criticism approach to the gospels may be content to try to uncover the individual authors' motivation in crafting or recrafting their manuscripts in order to create the distinctive differences between the four accounts of Jesus' entry into Jerusalem, the reader-perspective approach to the gospels places critical emphasis in another direction. According to this approach, the focus of attention moves from the author to the reader, and with the change of focus comes a change in the academic tools appropriate for undertaking the relevant investigation. While the redactioncritical approach attempts to uncover the motivations of longdeceased authors, the reader-perspective approach attempts to hear the voices and to discover the motivations of living flesh-and-blood readers. Therefore, it becomes appropriate for the reader-perspective approach to draw on the insights, theories and methods of enquiry refined within the social sciences, perhaps in particular those refined by sociology and by psychology.

In the early development of the reader-perspective approach, dialogue with sociology became visible. The readerperspective approach was shaped by the development of ideologically driven approaches of interpreting the Bible. Such ideologically driven approaches often engaged with theories and categories developed within sociological enquiry. Feminist, liberation, black and post-colonial approaches to biblical hermeneutics all stressed the importance of the social location of readers in shaping meaning (Segovia \& Tolbert 1995a, 1995b). Along with the growth of what is generally termed 'cultural studies' (Easthope 1991; Guerin, et al. 2005; Segovia 1995), these approaches emphasised that what a text means often depends on what sort of people are reading it, and in particular on their social background.

These ideologically diverse reader-centred approaches have been joined by others that either draw on postmodern insights (Adam 1995; Aichele et al. 1995) or are heavily influenced by the individuality of the reader (Kitzberger 1999). In contrast to historical or literary approaches, reader-centred approaches to biblical hermeneutics are less interested in seeking and extracting objective meaning from the text and more interested in the meanings that readers create. The recognition and acceptance of pluralism, subjectivity and the enculturation of meaning leads to a very different understanding of the purpose of biblical interpretation. It is less about extracting timeless truths from the text and more about the text being drawn into the world of the reader. In this approach the revelatory power of text emerges in the engaged consideration between the reader and the texts in the Bible. Moreover, in a community approach to engagement with the Bible, it becomes less a matter of the individual reader and more a matter of the community of readers. The revelatory power of a text emerges in the engaged conversation between the people of God (the gathered community in that place) and the Word of God actively engaged by that community.

More recent developments in the reader-perspective approach have concentrated on the insights that may be drawn from psychological theories relevant to the broader field of hermeneutics. This is a sensible strategy, given that a primary concern of some traditions within psychology is with the perceiving and evaluating functions of the human mind, and given that perception and evaluation are core mental activities involved in the interpretation and application of text. Within this context, the notions of perceiving and evaluating are central to the model of psychological functioning proposed by psychological type theory as introduced by Jung (1971) and as developed, extended and operationalised by a series of psychological measures, including the Keirsey Temperament Sorter (Keirsey \& Bates 1978), the Myers-Briggs Type Indicator (Myers \& McCaulley 1985) and the Francis Psychological Type Scales (Francis 2005).

\section{Psychological type theory}

At its core, psychological type theory identifies two distinct psychological processes, the first described as the 'perceiving process' and the second described as the 'evaluating' or 'judging process'. The perceiving process is styled as the irrational process, because it is concerned with the ways in which information is gathered; the perceiving process does not evaluate or make judgement about that data. The judging or evaluating process is styled as the rational process, because it is concerned with the ways in which information is evaluated. The perceiving process operates through two different functions: the sensing function (S), which is concerned with details, and the intuitive function (I), which is concerned with the overview. The judging or evaluating process also operates through two different functions: the feeling function $(\mathrm{F})$, which is concerned with personal and interpersonal values, and the thinking function (T), which is concerned with objectivity and logic. According to this theory, people need to be able to draw on all four functions, but they generally develop one perceiving function more strongly than the other (sensing or intuition) and one judging or evaluating function over the other (thinking or feeling). The analogy is with human handedness, where most people tend to develop skills with one hand, to the comparative neglect of the other hand.

While instruments designed to assess psychological type, like the Myers-Briggs Type Indicator (Myers \& McCauley 1985), identify additional type factors, these do not directly 
affect the hermeneutical approach to the text and so are less relevant to exploring the reader's interpretation.

\section{Psychological type and biblical hermeneutics}

The relevance of psychological type theory for biblical hermeneutics was first given serious voice by Stiefel (1992). A much more sustained consideration of the contribution of psychological type theory for biblical hermeneutics and liturgical preaching was advanced by Francis and Village (2008) in their documentation of what they style as 'the SIFT approach', drawing on earlier discussions advanced by Francis $(1997,2003)$ and by Francis and Atkins (2000, 2001, 2002). In essence the SIFT approach offers a systematic method of addressing the text of scripture (including the descriptive details, issues of character, plot and actions) by applying the four psychological functions in turn, beginning with the two perceiving functions and then progressing to the judging functions.

The first step in the SIFT method addresses the sensing perspective. It is this perspective that focuses on the details of the text and draws on the insights of the historical methods of biblical scholarship. The sensing questions ask: 'What is there to see, to hear, to touch, to smell and to taste?'

The second step in the SIFT method addresses the intuitive perspective. It is this perspective that relates the text to wider concerns and issues. The intuitive questions ask: 'What is there to speak to the imagination, to forge links with current situations, to illuminate issues in our lives?'

The third step in the SIFT method addresses the feeling perspective. It is this perspective that examines the human interest in the text and seeks out the insights for compassionate and harmonious living. The feeling questions ask: 'What is there to speak about the relationships between people, about fundamental human values and about what it is to be truly human?'

The fourth step in the SIFT method addresses the thinking perspective. It is this perspective that examines the theological interest in the text and seeks out the critical and rational insights on issues of principle. The thinking questions ask: 'What is there to speak to the mind, to challenge us on issues of justice and truth and to provoke profound theological thinking?'

Sound dialogue with the social sciences brings to the field of biblical hermeneutics not only a range of theories grounded in sociological or psychological observation but also a sense of responsibility (or obligation) to test those theories with empirical science, drawing on recognised quantitative and qualitative methodologies. Both methods have been set to work in recent empirical studies designed to test the application of psychological type theory proposed by the SIFT approach.

\section{Empirical approaches}

Three studies have used a quantitative approach to test the application of psychological type theory to biblical hermeneutics as proposed by the SIFT method. In the first study, Village and Francis (2005) invited lay adult Anglicans to read a healing story from Mark's Gospel and then to identify their preferences among interpretative statements that distinguished between sensing and intuition (the perceiving functions) or between thinking and feeling (the judging functions). The data demonstrated that these lay adult Anglicans preferred interpretations that matched their psychological type preferences in both the perceiving process and the judging process.

In the second study, Francis, Robbins and Village (2009) invited experienced preachers to read Mark 1:29-39 and then to rate their appreciation of the four reflections on this passage offered by Francis (1997) to illustrate sensing, intuitive, feeling and thinking approaches to that passage. The data demonstrated that preachers were four times more likely to prefer a sensing interpretation of the text rather than a thinking interpretation, emphasising the richness of the narrative rather than facing the theological questions posed by it.

In the third study, Village (2010) invited recently ordained Anglican clergy serving in England, Ireland, Scotland and Wales to read the healing story from Mark 9:14-29 and to select between interpretative statements designed to appeal to particular psychological type preferences. The data demonstrated that, after controlling for differences in biblical conservatism, preferences for interpretation were significantly correlated with psychological type function preferences in both the perceiving process and the judging process.

Nine studies have used a qualitative approach to test the application of psychological type theory to biblical hermeneutics as proposed by the SIFT method. Each of these studies has focused on specific passages of scripture and invited participants to work together in groups that have drawn together individuals of similar psychological type preferences. In turn these nine studies have explored reader responses to the following passages of scripture: the feeding of the five thousand from Mark 6:34-44 (Francis 2010); the resurrection narratives from Mark 16:1-8 and Matthew 28:1-15 (Francis \& Jones 2011); the Johannine feeding narrative from John 6:4-22 (Francis 2012a); the cleansing of the temple from Mark 11:11-21 (Francis 2012b); the separation of sheep from goats in Matthew 25:31-46 (Francis \& Smith 2012); the birth narratives from Matthew 2:13-20 and Luke 2:8-16 (Francis \& Smith 2013); the Advent call of John the Baptist from Mark 1:2-8 and Luke 3:7-17 (Francis 2013; Francis \& Smith 2014); and the Johannine feeding narrative from John 6:5-15 (Francis \& Jones 2014).

The cumulative evidence generated by these nine studies has begun to ground the SIFT approach on secure empirically 
based foundations. The evidence supports the view that distinctive approaches to reading and to proclaiming scripture are linked with the psychological type preferences of the reader or of the preacher. In line with the underlying theory, sensing types tend to find it difficult to step outside the text to identify the larger themes or to link with other fields of experience, but they excel at getting to grips with the details in the passage. Intuitive types tend to find it difficult to stay with, or even to notice, the details in the passage, but they excel at forging links with other fields of experience and with identifying the larger themes. Feeling types tend to shy away from the more problematic, conflictual and contested theological issues latent within the passage, but they excel at identifying the human, personal and interpersonal experiences and values and at spotting matters of harmony, peace and reconciliation. Thinking types tend to shy away from the human narrative, but they excel at identifying and analysing the underlying theological issues raised by the passage and at spotting matters of truth, fairness and justice.

\section{Research question}

Against this background, the aim of the present empirical study is to build on the recent qualitative research tradition established by Francis (2010, 2012a, 2012b, 2013), Francis and Jones $(2011,2014)$ and Francis and Smith $(2012,2013$, 2014) in order to explore how psychological type preferences are reflected in approaches to the Marcan account of Jesus riding into Jerusalem on a donkey, cursing the fig tree and overturning the tables of the money changers in the temple in Mark 11:11-21 (see Appendix). In order to distinguish clearly between the role of the perceiving functions (sensing and intuition) and the role of the judging functions (thinking and feeling), the research will be conducted in two phases and draw on different participants for these two phases. The task given to the participants in phase 1 will focus on activity that draws on the perceiving process. The task given to the participants in phase 2 will focus on activity that draws on the judging process. Particular emphasis was given to these tasks by the context in which the workshops were located: both phase 1 and phase 2 took place in the context of (different) residential programmes concerned with Christian responses to conflict.

\section{Phase 1: The perceiving process \\ Procedure}

In the context of a residential programme concerned with biblical interpretation and conflict, 18 type-aware participants were invited to work in three groups organised according to type preferences on the perceiving process. Participants were given a copy of Mark 11:11-21, and this passage was read aloud to all participants before they dispersed into type-alike groups. In the groups they were asked to address the following activity: Use your perceiving functions (sensing and intuition). What do you see in the narrative? What sparks your imagination in this narrative? The groups were asked to work on this task and to agree on a common presentation of their conclusions. One of the authors served as a nonparticipant observer in the group of six high-scoring intuitive types and the other author served as a non-participant observer in the group of six high-scoring sensing types in order to take detailed notes of the discussion. The highscoring participants were drawn together in this way in order to concentrate the distinctive type preferences within the groups on which the analysis is based.

\section{Results}

The intuitive group opened the conversation immediately by announcing a large theme dominating the passage: 'I see a very, very angry man'. Jesus is cross with the fig tree. He is outraged by the temple. He is so cross that he cannot even stay in Jerusalem. He retreats back to Bethany, where he has good friends who can calm him down. 'I see a driven, incommunicative man'. Jesus takes action first and speaks afterwards. Jesus drives people out of the temple. In John's Gospel Jesus even made a whip to drive them out! He overturns the tables of the money changers. He overturns the tables of those selling pigeons. The pigeons are flapping around everywhere. There is chaos. Then Jesus calms down enough to explain his activities, calling on scripture: 'My house shall be called a house of prayer for all nations'. 'But you have made it a robbers' cave'. Jesus stamps his foot at the fig tree in utter rage. Then he curses it: 'May no one ever eat fruit from you again'.

'I see a man who is very, very angry and yet is clear thinking and plans his strategy'. He had planned his entry into Jerusalem with care. He had booked the donkeys in advance and kept his plan secret to the last minute. He had orchestrated his followers to draw on the images of the Maccabees, to enact images from the prophets and to shout psalms of enthronement. He had taken a calm look around the temple, walked out when the temple police would be off guard and timed his attack. 'I see a very, very angry man who does not reason with people'. Jesus never reasons with people. You cannot reason with people. They will not understand. It is the actions that say it all. The temple is finished. The fig tree is finished. Israel is finished. Once the money changers' tables have been overturned, the whole political economy is finished.

'I see a very, very angry man who is now finished'. What Jesus did in the temple had no lasting effect. It was no more than an early closing for the rest of that day, and the next day would be business as usual. What Jesus had done was reported to the temple police and they decided to get rid of him. They could not risk a repeat performance. You cannot do this with the temple and get away with it. Their policy was now to kill Jesus; their strategy was to find the right time to do it.

Underpinning this intuitive reflection on the narrative was commitment to exploring the theme of anger and exploring the place of anger in the Christian community. In this context 
Jesus himself became the symbol for radical Christianity and the model for radical extremism, offering both the divine imperative and displaying the absolute futility. Looking at Jesus' model we stand accused of looking confused and of acting like cowards.

When invited to reflect on the relative weight that they had given to the two tasks (What do you see in the story? What sparks your imagination?), the intuitive group reported that they had not really noticed the first question but thoroughly enjoyed the second question.

The sensing group was slower to gain energy from the task set but did settle down to identify what they saw in the passage. They separated out discussion about four discrete components of the narrative. They talked about Bethany, about the temple, about the fig tree and about Jesus. The perspective underlying this approach was neatly articulated by one of the participants, who said that she was concerned to see the passage as a clear account of 'what happened' and that she needed to see things as they unfolded.

Talk about Bethany drew together information from a variety of sources. Memories of Bible maps confirmed that Bethany was indeed not far from Jerusalem. Memories of Luke's Gospel confirmed that Jesus felt at home in Bethany as guests of the two sisters, Mary and Martha. Martha's skill in the kitchen, Mary's attention to Jesus' teaching and the domestic dispute between the two sisters adding enriching sensing texture to the location. Memories of John's Gospel brought the sisters' brother into conversation. It was in Bethany that Lazarus was called forth from the tomb.

Talk about the temple recalled the central importance of the temple for the Jewish tradition. Memories of the history of first-century Palestine recalled how the temple was functioning within an occupied land under Roman rule. The temple only survived because of the political concordat respecting the Jewish religion within the Roman Empire. The money changers were there in the temple courtyard because Jewish currency was needed to purchase the animals for sacrifice, while Roman currency served the daily needs of the marketplace. The birds were there because they provided an affordable sacrifice for ordinary people.

Talk about the fig tree caused some to puzzle about the seasons and about the time of year. Was it reasonable to expect figs to be ready for picking at the time of the Passover? Some textual issues were raised about how Mark's account is different from Luke's and whether Mark's account is a misplaced parable. The question was raised as to whether this event ever really happened or whether it was an enacted parable like the triumphal entry into Jerusalem while riding on a donkey.

Talk about Jesus concluded that the text does not give us access to what was in his mind. Jesus' actions could indicate that he had lost his temper, but they could equally have been a well-planned and calculated part of the enacted parable. The dramatic entry into Jerusalem, riding on the donkey and accompanied by the Davidic psalms of enthronement and by the palm branches reminiscent of the Maccabees, led, naturally, to the dramatic occupation of the temple, clearing the temple of evidence of dependency on Roman currency.

Once started, each of these four components of the narrative generated its own energy. When invited to reflect on the relative weight that they had given to the two tasks (what do you see in the story? what sparks your imagination?), the sensing group reported that they had become so absorbed in the first question that they had not left time to deal with the second question.

\section{Phase 2: The judging process Procedure}

In the context of a residential programme concerned with psychological type and conflict within Christian communities, 24 type-aware participants were invited to work in four groups organised according to type preferences on the judging process. Participants were given a copy of Mark $11: 11-21$, and this passage was read aloud to all participants before they dispersed into type-alike groups. In the groups they were asked to address the following activity: Use your preferred judging function (feeling or thinking). Recalling the context of the passage in Mark's Gospel, what can Christians today learn about the causes, management and consequences of conflict? The groups were asked to work on this task and to agree on a common presentation of their conclusions. One of the authors served as a non-participant observer in the group of six high-scoring feeling types and the other as a non-participant observer in the group of six high-scoring thinking types in order to take detailed notes of the discussion. The high-scoring participants were drawn together in this way in order to concentrate the distinctive type preferences within the groups on which the analysis is based.

\section{Results}

The thinking group began by analysing the puzzling features of the narrative, and for some these puzzling features emerged into prominence for the first time. Why did Jesus go into the temple after the Palm Sunday journey to Jerusalem when it was already too late to achieve anything? Why did Jesus curse the fig tree for failing to offer fruit when it was so clearly not the season for figs? How do the two narratives hang together (concerning the fig tree and concerning the temple) and what did Mark intend by placing them together?

The thinking group then drew on extra-textual knowledge to give more substance to the context in which the Marcan narrative was located. None of this narrative about the fig tree and about the temple made real sense without the Palm Sunday entry. Here was a politically charged and religiously motivated act of insurrection at a season (Passover) when Jerusalem was overflowing with Jews who had come to the 
city to celebrate God's saving and liberating escape from oppression when Moses led God's people through the Red Sea. When Jesus walked into Jerusalem, he could either have turned right to confront the Roman fortress or left to embrace the temple.

Next the thinking group tried to reconcile the discontinuity between the two narratives (the fig tree and the temple). This was clarified as a 'typical Marcan sandwich' where one narrative illuminated the other. The fig tree was reconceptualised as the people of God, who were failing to bring forth the fruit that God desired of them. The temple, likewise, was failing to bring forth the fruit that God desired of it. Only after these matters had been settled was the thinking group ready to distil from the passage's responses to the core questions: What can Christians learn about the causes, management and consequences of conflict from this passage?

In one sense, the underlying causes of the conflict were the fundamental disagreements between God and the people of Israel, who were not living up to their call. The conflict has been well documented in scripture and the remedy is radical. The axe has already been laid at the roots. The Christ comes not to bring peace but the sword to this situation.

In another sense, the precipitative cause of conflict was Jesus himself. The Palm Sunday entry to Jerusalem was inflammatory at the time of celebrating the Passover. The donkey carried echoes of Isaiah, the palm branches carried echoes of the Maccabees and the choice of shouts of praise from the enthronement psalms promised the restoration of Davidic kingship. In all this Jesus was orchestrating conflict.

These reflections on the cause of conflict led to insights into the management of conflict. Close scrutiny suggested that the whole scenario from Palm Sunday to Good Friday had been managed by Jesus. Even the donkeys for the journey had not been left to chance but set up secretly in advance. The reconnaissance at dusk on the first evening was no accident, but Jesus had taken the opportunity to spy out the ground and to prepare the disruption.

Discussion of the management of conflict turned attention back to an analysis of how the Christian community may manage conflict. Jesus did not shy away from speaking truth to people of power, but his skill was choosing the right time to do so (kairos). The real call for judgement today in dealing with conflict is to get the timing right. Incisive action prematurely can fail to carry people with it. Incisive action too delayed can fail to deal with the problem in time and as a consequence the problem just grows worse. Conflict-averse clergy, it was observed, generally leave intervention too late.

The thinking group identified an inevitable logic in the consequences of conflict. For the fig tree, the consequences were immediate death. For Jesus, the consequences were seen in the way in which the chief priests and scribes simply had to deal with the threat by taking him out of the situation: they could not run the risk of Jesus being kept alive. For the temple, the consequences were seen in the destruction wrought by the Roman occupation in AD 70. Once Jesus had taken the lid off, the Passion narrative was inevitable.

The lessons for Christians today include the following: the willingness to precipitate conflict when conflict is needed; the judicial evaluation of when the time is right to precipitate conflict and the responsibility to get the time right; and the wisdom to predict the consequences and to face up to those consequences. However, Jesus' management of conflict led not only to crucifixion but also to resurrection.

The feeling group moved directly to a discussion about their uncomfortable feelings arising from Jesus' treatment of the fig tree. Two particular sources of discomfort were identified and supported by the group. Firstly, the fig tree had been treated unfairly; if it were not the season for figs, how could the fig tree be blamed for not producing fruit? Secondly, Jesus' actions appeared to be marked by strong emotional responses and irrationality; as one person stated, this kind of teaching was discordant with that found in the 'rest of the Bible'.

It was quickly agreed that a literal reading of the fig tree narrative was not acceptable, because of the implications for their understanding of Jesus. The group then began to explore the text in terms of analogy, as a way of interpreting why Jesus had spoken and acted as he did in relation to the fig tree. There was general support for the position that the real subject being presented in the passage was the relationship between the old covenant and the new covenant, with the old covenant being condemned because it had ceased to bear fruit. The strong language and actions would be 'understandable' in this context, and group members cited other New Testament texts where the old covenant (or the Jewish religious authorities) were spoken about and addressed in equally strong ways. As one person commented, 'We cannot make sense of this, if it is not an analogy'.

The feeling group, however, was not only concerned about the fig tree but also about Jesus during the fig tree episode. Efforts were made to try to describe and understand Jesus' emotional state. For example, drawing on the information given in the passage, it was deduced that from a human perspective, Jesus would have been very tired and hungry, and this would help to explain this 'burst' of strong emotion when he discovered the fig tree without any fruit. Some shared their sense (and perhaps disquiet) that there was something 'unbalanced' about Jesus in the fig tree episode and thought that it might be an opportunity to see the humanity of Jesus through his strong emotional response. This led to a question about whether his actions towards the fig tree were premeditated, and one person noted that the fig tree was 'picked out' from a distance, showing that this was a deliberate action and that Jesus went 'out of his way' to have this encounter with the fig tree. If this were the case, 
the argument continued, Jesus was intentionally acting out the analogy previously discussed by the group. However, one person commented that she was still troubled by Jesus' apparent act of 'cursing' and destroying the fig tree, and this led to a detailed discussion of the life cycle of fig trees in Near Eastern countries. The discomfort appeared to be resolved with the argument that the barren fig tree was likely to have been near the end of its life, and being no longer of any use it would have been cut down regardless of Jesus' action.

After the group had spent half of the allocated time discussing the fig tree and Jesus' emotional state, one person pointed out that they had not dealt with anything else in the passage. It was noted that, since the fig tree narrative was wrapped around the temple incident, it was necessary to look at the whole passage. As the group had now begun to understand Jesus' emotional state in dealing with the fig tree, they anticipated that there would be a close relationship between this and Jesus' action in the temple. The first explicit attempt to relate the passage to conflict occurred at this stage, and the reasons why the temple incident was a conflict situation were explored. It was agreed that the temple and its activity would have been perceived differently by various groups. The presence of money changers and the selling of acceptable and 'pure' offerings in the temple would have led to a number of abuses, including monopoly in the market and unfair prices (contemporary examples of this were used as illustrations). Some people at the time would have viewed this as unethical practice and as defiling this place of worship. This stance was then related to Jesus and, as one person observed, what Jesus saw would have been 'defiling and offending his deeply held values concerning what the temple was about'. The group agreed that the conflict was about a clash of values: the temple values of the establishment and the deeply held values of Jesus.

The feeling group then turned to the action of Jesus in the temple and agreed that physically overturning tables publicly was very radical, clear and powerful. It was also plain that Jesus had instigated the conflict, which was difficult for the feeling group to appreciate. This raised an important question: could this have been done another way? Could Jesus not have approached people privately and hid 'behind the scenes?' Did such a public display make any real difference to the situation in the temple, except perhaps moving Jesus closer to his death? The group returned once more to explore whether Jesus was 'out of control' in the passage or not. One person empathised through personal experience with losing control and appearing to act out of character when deeply held values are challenged. This experience was affirmed by other members of the group.

The only point of clearly critical (but moderately expressed) disagreement arose in the group at this point, centred around the questions 'how much was Jesus in control?' and 'how much was Jesus aware of the overall plan?' This led to a discussion about how to theologically understand the human and divine aspects of Jesus and how these related to gospel texts. A range of views was expressed, but the majority of the group preferred (in varying strengths) a focus on and appreciation of the humanity of Jesus, and this seemed important for their understanding of both the current passage and the person of Jesus.

As the end of the session drew close, the feeling group was keen to agree on a unanimous presentation. They agreed that feeling types want to avoid conflict but that there are times when feeling types need to act like Jesus did in the passage, or as one person said: 'We do have to stand up, be counted and take the consequences'. From this starting point, the feeling group agreed on the following two conclusions (and minor modifications suggested to the wording were readily incorporated). Firstly, they agreed that there may be a time when even feeling types need to be forceful and instigate conflict. The fig tree and the temple should have been a source of nourishment but they were not. 'Even an F needs to use T'. Secondly, they agreed that they should ask whether there are places today where we should be acting in this way and whether it makes any difference (some felt that they could only act in 'small ways' but when examples were provided of individuals making a difference to corporations, it was agreed that this was possible and could have an effect).

Overall what was important to the feeling group was the idea that conflict should be motivated by genuine values and that conflict should lead to human benefit.

\section{Conclusion}

This study identified the Marcan account of Jesus riding into Jerusalem on a donkey, cursing the fig tree and overturning the tables of the money changers in the temple as providing a classic scriptural reference point for a Christian discussion of conflict. Emphasis was placed on the reader-perspective approach, focusing on the present-day readers of the Gospel narratives and on the theoretical understanding of biblical hermeneutics shaped by psychological type theory.

Responding to the argument that the proper understanding of reader perspective needs to be grounded in empirical research professionally shaped within traditions developed by the social sciences and building on a series of studies reported by Francis (2010, 2012a, 2012b, 2013), Francis and Jones $(2011,2014)$ and Francis and Smith $(2012,2013,2014)$, the present study reported on an original qualitative study conducted in two phases. Phase 1 explored the role of the perceiving process by examining how a group of sensing types and a group of intuitive types responded to the following focused task: What do you see in the narrative? What sparks your imagination in the narrative? Phase 2 explored the role of the judging process by examining how a group of thinking types and a group of feeling types responded to the following focused task: Use your preferred judging function (feeling or thinking). Recalling the context of the passage in Mark's Gospel, what can Christians learn 
today about the causes, management and consequences of conflict? The following two main conclusions emerge from the data generated by this empirical enquiry.

The first conclusion concerns the ways in which individuals read, reflect on and interpret scripture, reflecting their own personal psychological preferences. Feeling types really do give priority to the personal and interpersonal implications, and thinking types really do go for an analysis of the issues raised. Sensing types really do worry about the details of the text in front of them, while intuitive types really do search for overarching grand themes to the neglect of the details in the text. A reader perspective on biblical hermeneutics in relation to conflict may be incomplete, if the contribution of psychological type theory is not taken into account.

The second conclusion is that when groups are fashioned according to similar preferences in the perceiving or judging process, an energising harmony is created within the group. Individuals are able to express their views with confidence, safe in the knowledge that they are in the company of the like-minded. A safe space is created for views to be expressed that might be seen as controversial in other settings. Therefore, this kind of engagement with scripture allows depth in the hermeneutical process and recognition of a distinctive 'reading' that is both shared and enriched through articulation and exploration with like-minded others. However, one distinctive 'reading' alone is unable to offer breadth in the hermeneutical process, and for this reason a hermeneutical process informed by one preference in psychological type theory is incomplete without a subsequent and secondary engagement with other reader perspectives, drawing on different preferences in the perceiving and judging process.

\section{Acknowledgements Competing interests}

The authors declare that they have no financial or personal relationships that may have inappropriately influenced them in writing this article.

\section{Authors' contributions}

L.J.F. originated the theoretical framework within which this project was located. L.J.F. and T.A.S. shared equally in the design, conceptualisation and execution of this specific experiment. They worked together with the participants and shared equally in the analysis of the data in crafting the results section and in formulating the conclusions.

\section{References}

Adam, A.K.M., 1995, What is postmodern biblical criticism?, Fortress Press, Minneapolis, MN.

Aichele, G., Burnett, F.W., Castelli, E.A., Fowler, R.M., Jobling, D., Moore, S.D. et al. (eds.), 1995, The post-modern Bible, Yale University Press, New Haven, CT.

Dibelius, M., 1971, From tradition to Gospel: Gospel criticism and Christology, transl. B.L. Woolf, James Clark and Co. Ltd, Cambridge.

Easthope, A., 1991, Literary into cultural studies, Routledge, London.
Francis, L.J., 1997, Personality type and scripture: Exploring Mark's Gospel, Mowbray, London.

Francis, L.J., 2003, 'Psychological type and biblical hermeneutics: SIFT method of preaching', Rural Theology 1, 13-23. http://dx.doi.org/10.1179/rut_2003_1_ 1 1_002

Francis, L.J., 2005, Faith and psychology: Personality, religion and the individual, Darton, Longman and Todd, London.

Francis, L.J., 2010, 'Five loaves and two fishes: An empirical study in psychological type and biblical hermeneutics among Anglican preachers', HTS Theological Studies/ Teologiese Studies 66(1), Art. \#811, 1-5. http://dx.doi.org/10.4102/hts.v66i1.811

Francis, L.J., 2012a, 'Interpreting and responding to the Johannine feeding narrative: An empirical study in the SIFT hermeneutical method among Anglican ministry training candidates', HTS Theological Studies/Teologiese Studies 68(1), Art. \#1205, 1-9. http://dx.doi.org/10.4102/hts.v68i1.1205

Francis, L.J., 2012b, 'What happened to the fig tree? An empirical study in psychological type and biblical hermeneutics', Mental Health, Religion and Culture 15, 873-891. http://dx.doi.org/10.1080/13674676.2012.676252

Francis, L.J., 2013, 'Ordinary readers and reader perspective on sacred texts: Drawing on empirical theology and Jungian psychology', in J. Astley \& L.J. Francis (eds.), Exploring ordinary theology: Dimensions of everyday Christian existence and the life of the Church, pp. 87-96, Ashgate, Farnham.

Francis, L.J. \& Atkins, P., 2000, Exploring Luke's Gospel: A guide to the gospel readings in the Revised Common Lectionary, Mowbray, London.

Francis, L.J. \& Atkins, P., 2001, Exploring Matthew's Gospel: A guide to the gospel readings in the Revised Common Lectionary, Mowbray, London.

Francis, L.J. \& Atkins, P., 2002, Exploring Mark's Gospel: An aid for readers and preachers using year B of the Revised Common Lectionary, Continuum, London.

Francis, L.J., Robbins, M. \& Village, A., 2009, 'Psychological type and the pulpit: An empirical enquiry concerning preachers and the SIFT method of biblical hermeneutics', HTS Theological Studies/Teologiese Studies 65(1), Art. \#161, 1-7. http://dx.doi.org/10.4102/hts.v65i1.161

Francis, L.J. \& Jones, S.H., 2011, 'Reading and proclaiming the resurrection: An empirical study in psychological type theory among trainee and experienced preachers employing Mark 16 and Matthew 28', Journal of Empirical Theology 24 1-18. http://dx.doi.org/10.1163/157092511X571141

Francis, L.J. \& Jones, S.H., 2014, 'Life in the eucharistic community: An empirical study in psychological type theory and biblical hermeneutics reading John 6: 5-15', Pastoral Psychology 63, 281-290. http://dx.doi.org/10.1007/s11089-013-0540-x

Francis, L.J. \& Smith, G., 2012, 'Separating sheep from goats: Using psychological type theory in a preaching workshop on Matthew 25: 31-46', Journal of Adult Theological Education 9, 175-191. http://dx.doi.org/10.1179/ate.9.2. gw21522035374468

Francis, L.J. \& Smith, G., 2013, 'Reading and proclaiming the birth narratives from Luke and Matthew: A study in empirical theology among curates and their training incumbents employing the SIFT method', HTS Theological Studies/Teologiese incumbents employing the SIFT method,' HTS Theological Studies/Teold

Francis, L.J. \& Smith, G., 2014, 'Reading and proclaiming the Advent call of John the Baptist: An empirical enquiry employing the SIFT method', HTS Theological Studies/Teologiese Studies 70(1), Art. \#2718, 1-9. http://dx.doi.org/10.4102/hts. v70i1.2718

Francis, L.J. \& Village, A., 2008, Preaching with all our souls, Continuum, London.

Guerin, W.L., Labor, E., Morgan, L., Reesman, J.C. \& Willingham, J.R., 2005, A handbook of critical approaches to literature, Oxford University Press, New York.

Jung, C.G., 1971, Psychological types: The collected works, vol. 6, Routledge and Kegan Paul, London.

Keirsey, D. \& Bates, M., 1978, Please understand me, Prometheus Nemesis, Del Mar, CA.

Kitzberger, I.R. (ed.), 1999, The personal voice in biblical interpretation, Routledge, London.

Myers, I.B. \& McCaulley, M.H., 1985, Manual: A guide to the development and use of the Myers-Briggs type indicator, Consulting Psychologists Press, Palo Alto, CA.

Rohde, J., 1968, Rediscovering the teaching of the evangelists, transl. D.M. Barton, SCM Press, London.

Segovia, F.F., 1995, 'Toward a hermeneutic of the diaspora: A hermeneutic of otherness and engagement', in F.F. Segovia \& M.A. Tolbert (eds.), Readings from this place: Social location and biblical interpretation in the United States, pp. 57-73, Fortress Press, Minneapolis, MN.

Segovia, F.F. \& Tolbert, M.A. (eds.), 1995a, Reading from this place: Social location and biblical interpretation in the United States, Fortress Press, Minneapolis, MN.

Segovia, F.F. \& Tolbert, M.A. (eds.), 1995b, Readings from this place: Social location and biblical interpretation in global perspective, Fortress Press, Minneapolis, MN.

Sparks, H.F.D., 1964, A synopsis of the Gospels: The synoptic Gospels with the Johannine parallels, Adam and Charles Black, London.

Stiefel, R.E., 1992, 'Preaching to all the people: The use of Jungian typology and the Myers-Briggs type indicator in the teaching of preaching and in the preparation of sermons', Anglican Theological Review 72, 175-202.

Village, A., 2010, 'Psychological type and biblical interpretation among Anglican clergy in the UK', Journal of Empirical Theology 23, 179-200. http://dx.doi.org/ 10.1163/157092510X527349

Village, A. \& Francis, L.J., 2005, 'The relationship of psychological type preferences to biblical interpretation', Journal of Empirical Theology 18, 74-89. http://dx.doi. org/10.1163/1570925054048929 


\section{Appendix}

\section{Mark 11:11-21}

${ }^{11}$ Then he entered Jerusalem and went into the temple; and when he had looked around at everything, as it was already late, he went out to Bethany with the twelve.

${ }^{12}$ On the following day, when they came from Bethany, he was hungry. ${ }^{13}$ Seeing in the distance a fig tree in leaf, he went to see whether perhaps he would find anything on it. When he came to it, he found nothing but leaves, for it was not the season for figs. ${ }^{14} \mathrm{He}$ said to it, 'May no one ever eat fruit from you again'. And his disciples heard it.

${ }^{15}$ Then they came to Jerusalem. And he entered the temple and began to drive out those who were selling and those who were buying in the temple, and he overturned the tables of the money changers and the seats of those who sold doves; ${ }^{16}$ and he would not allow anyone to carry anything through the temple. ${ }^{17} \mathrm{He}$ was teaching and saying, "Is it not written, "My house shall be called a house of prayer for all the nations"? But you have made it a den of robbers'.

${ }^{18} \mathrm{And}$ when the chief priests and the scribes heard it, they kept looking for a way to kill him; for they were afraid of him, because the whole crowd was spellbound by his teaching. ${ }^{19} \mathrm{And}$ when evening came, Jesus and his disciples went out of the city.

${ }^{20}$ In the morning as they passed by, they saw the fig tree withered away to its roots. ${ }^{21}$ Then Peter remembered and said to him, 'Rabbi, look! The fig tree that you cursed has withered'. 